\section{A natural education}

\section{Andrew Whiten}

Feral Children and Clever Animals: Reflections on Human Nature. By Douglas Keith Candland. Oxford University Press: 1993. Pp. 411. \$30.

ON 17 October 1920 near Midnapore in India, the Reverend A. J. Singh sought to drive out the ghosts that local people reported to inhabit a wolf's den. The mother wolf was shot and the den was dug out. Singh's diary recorded what they found: "the two cubs and the other two hideous beings were there in one corner, all four clutching together in a monkeyball. The ghosts were more ferocious than the cubs, making faces, showing teeth, making for us when too much disturbed, and running back to form the monkey-ball." By this account the girls, later named Kamala and Amala, were true wolf-children. Together with the other 'wild' or feral children who occupy the first part of Candland's book, these wolf children are inevitable objects of curiosity for all those who seek to delineate the bounds of human nature.

Curiously, the mirrorimage of such nightmarish scenarios is with us daily as we rear puppies in our homes, without undue concern about the implications for understanding either dog or human nature. Yet, when the species to be

human-reared is an ape with a brain more like our own, excitement grows again about the prospects for understanding the scope of our own nature in the comparison. Attempts to home-rear apes and teach them language form the fourth and final part of the book.

Between these in-depth accounts of feral children and civilized apes, Candland sandwiches analyses of a gamut of other studies from the past century, which offer to illuminate human nature, typically through human-animal linkages and comparisons. Through the surprising diversity of studies that Candland binds to this central task, he succeeds in another major achievement - an eye-opening history of psychology. Candland's meticulous scholarship repeatedly reveals subplots and obscure yet important details surrounding famous studies that have all too often become distorted or diminished in contemporary textbooks. Thus, for example, when we hear of Pfungst's wellducted elsewhere by Karl Krall; that Renng by Hans and a dog; and that further efforts to teach dogs to speak or communicate using signs anticipated contemporary efforts to teach apes sign language by over half a century.

But Candland has another major theme: that whatever the conclusions of the studies discussed, the particular ways in which investigators frame their questions tell us a great deal about what it is to be human. The thinking of human beings who act as investigators shows them to be children of their age and culture: what pre-darwinians expected to learn from feral children was fundamentally different from later preoccupations with their 'animal instincts', for example. But complementing this cultural relativity is at least one constant theme that addresses what it is to be human: the drive to worm one's way into others' minds. A preoccupation that surfaces repeatedly is how to reveal the psychological experiences of those who are congenitally dumb - known dismissal of counting by the horse 'Clever Hans' as merely cued by his trainer von Osten, we also learn that Pfungst's hypothesis was never actually tested at the time; that after the famous critical work by Pfungst, Hans joined other horses in a series of more complex experiments condich made comparative studies of count- whether clever horse, ape, feral child or a child such as Laura Bridgman, totally blind and deaf. In the case of a feral child such as the 'wild boy of Aveyron', the idea of investigators was that if he could only be taught to speak, he would be able to say what it had been like to be a human being living in a 'state of nature'. In modern times the same heady objective has been espoused for what we may learn of the mental world of an ape that is taught language. And in between, Candland helps us to see the same goal being nursued in investigations ranging from that of Clever Hans to that of Little Hans, for in the latter, Freud equally endeavoured to establish communication with a normally silent mind, the elusive subconscious which in the $\frac{2}{2}$ case of the boy Hans he saw as identifying the father with an animal, the horse of which the boy was terrified. This psychoanalytic reference to the animal-in-man is yet another illustration of the complex web of themes that make this a highly original and thought톤 provoking book.

I suspect however, that many readers will, like myself, find too much undigested detail, coupled with a tendency to avoid setting out the specific conclusions we should be left with after such a rich and varied meal. This may be partly deliberate: one feels that Candland's strategy is to direct our attention to neglected issues, make wise comment, then sit back to let the reader struggle to his or her own conclusions.

Two sets of studies that are not referred to could have deepened our understanding of what light is cast on the nature of a species when its members are reared in isolation or by other species. One is work on the ontogeny of bird song, which, through sophisticated variations on 'Kaspar Hauser' deprivations and crossfostering, has greatly furthered our understanding of nature-nurture interaction. The other is Mason's rearing of monkeys with dog foster-mothers - the closest to a controlled and systematic version of the 'wolf-child' as we are likely to see. The monkeys acquired no obvious dog behaviour (which appears to contrast markedly with the wolf-like behaviour of Amala and Kamala), yet they lacked significant parts of what we should otherwise perceive as monkey nature.

Andrew Whiten is in the School of Psychology, University of St Andrews, Fife KY16 9SU, UK. 